DOI: https://doi.org/10.24144/2409-6857.2018.1(51).322-330

УДК 336.7:338.1

Дребіт Г.М.

\title{
АНАЛІТИЧНА СКЛАДОВА В ПЛАНУВАННІ ТА КОНТРОЛІ ГРОШОВИХ ПОТОКІВ ЕНЕРГОПОСТАЧАЛЬНИХ КОМПАНІЙ УКРАЇНИ
}

\begin{abstract}
Розглянуто проблеми аналізу та оцінки основних груп фінансових коефіцієнтів грошових потоків, які базуються на аналізі їх структури, достатності та ефективності, з метою підвищення якості планування та контролю грошових потоків енергопостачальних компаній Украӥни. В роботі, задля чіткої систематизації фінансових коефіиієнтів, які розраховуються на основі інформації щзодо грошових потоків підприємств автором виділено три основних групи коефіцієнтів грошових потоків: структурні коефіцієнти, коефіцієнти достатності грошових потоків, коефіцієнти ефективності грошових потоків. На основі проведеної оцінки згаданих фінансових коефіиієнтів, побудованих на базі грошових потоків досліджуваних енергопостачальних компаній протягом 2010-2016 років, зроблено відповідні висновки щцодо ефективного управління грошовими потоками в розрізі прогнозування та планування на майбутні аналізовані періоди, а також їх контролю.
\end{abstract}

Ключові слова: фінансові коефіиієнти, грошові потоки, сукупний грошовий потік, операиійний грошовий потік, інвестииійний грошовий потік, енергопостачальні компанї̈.

Постановка проблеми. В теорії і практиці корпоративних фінансів існує значна кількість фінансових коефіцієнтів, які розраховуються на основі інформації щодо грошових потоків підприємств. Наявність значної кількості коефіцієнтів та неоднозначність у підходах щодо методик їх розрахунку потребують чіткої систематизації зазначених фінансових коефіцієнтів та використання їх як ефективного інструмента контролю грошових потоків.

Аналіз останніх досліджень і публікацій. Теоретичні та практичні засади аналізу та оцінки грошових потоків підприємств стали предметом дослідження таких іноземних науковців як: Ю. Брігхем, М. Ерхардт, Д. Теннет, Ф. Фабоцці, П. Фернандез, Т. Мерна, та ін. [1-5]. Цим проблемам присвятили свої праці українські вчені: І.О. Бланк, Е.В. Виноградова, Ю.О. Срешко, Н.Ю.Іллічова, С.В. Каламбет, Л.Г. Кемарська, Л.О. Лігоненко, А.М.Поддєрьогін [6-12]. Ними зроблено значний внесок у розробку теоретикометодичних основ аналізу грошових потоків підприємств, проте питання оцінки грошових потоків для підвищення ефективності їх планування та контролю до специфічних категорій підприємств 3 врахуванням особливостей фінансово-господарської діяльності вимагає подальших наукових досліджень.

Формулювання цілей статті. Основними завданнями даного дослідження $\epsilon$ аналіз та

(C) Дребіт Галина Миколаївна, аспірантка кафедри корпоративних фінансів і контролінгу, Київський національний економічнй університет iм. В. Гетьмана, м. Київ, тел.: 0507426046; email: galyna-drebit@i.ua оцінка основних груп фінансових коефіцієнтів грошових потоків, які базуються на аналізі їх структури, достатності та ефективності, з метою підвищення якості їх планування та контролю.

Опис основного матеріалу дослідження. Задля чіткої систематизації фінансових коефіцієнтів, які розраховуються на основі інформації щодо грошових потоків підприємств та для використання їх як ефективного інструмента контролю грошових потоків, пропонуємо об'єднати основні фінансові коефіцієнти, які базуються на грошових потоках, у декілька наступних груп, виділивши в якості критерію функціональне призначення зазначених коефіцієнтів. Для планування та контролю грошових потоків пропонуємо виділяти три основних групи коефіцієнтів грошових потоків: структурні коефіцієнти, коефіцієнти достатності грошових потоків, коефіцієнти ефективності грошових потоків.

Кожен із зазначених коефіцієнтів може бути використаний як індикатор планування та контролю грошових потоків. В процесі планування грошових потоків необхідно використовувати планові значення зазначених коефіцієнтів в якості цільових індикаторів. Під час здійснення контролю грошових потоків фінансові коефіцієнти, які базуються на грошових потоках, можуть виступати інструментами контролю від час порівняння фактичних їх значень 3 плановими значеннями $\mathrm{i}$ виявлення відхилень.

До першої групи пропонуємо віднести коефіцієнти, які показують склад та структуру грошових потоків. Вони відображають частки внеску окремого виду грошового потоку в 
агрегований грошовий потік підприємства (вхідний чи вихідний, операційний, інвестиційний i фінансовий). По своїй суті вони виражають специфіку формування конкретного виду грошового потоку, визначають його склад і структуру.

У зв'язку з цим дані коефіцієнти можна назвати структурними коефіцієнтами грошових потоків. До таких коефіцієнтів належать: коефіцієнт участі операційного грошового потоку у формуванні сукупного грошового потоку за період $\left(\frac{K_{\text {OCF }}}{\text { TCF }}\right)$, коефіцієнт участі інвестиційного грошового потоку у формуванні сукупного грошового потоку за період $\left(\frac{K_{T C F}}{T C}\right)$, коефіцієнт участі фінансового грошового потоку у формуванні сукупного грошового потоку за період $\left(\frac{K_{\text {FICF }}}{T C F}\right)$.

\section{Зазначені}

коефіцієнти

можуть розраховуватись як по вхідному так i по вихідному грошовому потоках. Вони показують, яку частку займає кожен із видів грошових потоків (операційний, інвестиційний і фінансовий) у сукупному вхідному або вихідному грошовому потоці підприємства протягом певного періоду.

3 метою відображення узагальнених тенденцій, які притаманні для структурних коефіцієнтів грошових потоків, побудуємо рис. 1 та рис. 2, на яких відобразимо середні коефіціснти участі операційного, фінансового та інвестиційного грошових потоків у сукупному вхідному/вихідному грошових потоках енергопостачальних компаній України у 2010$2016 \mathrm{pp}$.

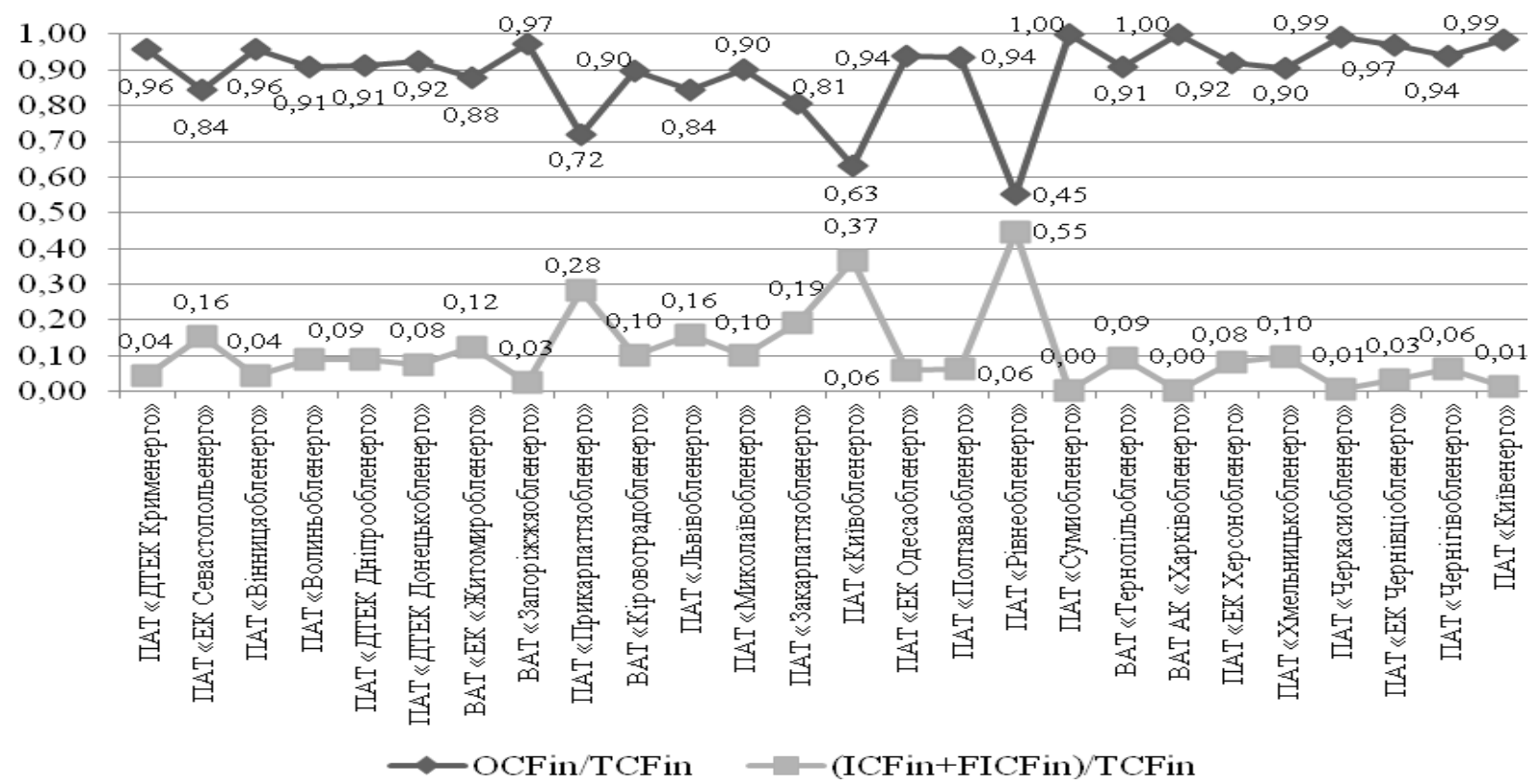

Рис.1. Середні значення коефіціснтів участі $O$ CF $_{\text {in }}$, ICF $_{\text {in }}$, FICF $_{\text {in y }}$ TCF $_{\text {in }}$ енергопостачальних компаній України за 2010-2016 рp.*

* Побудовано автором на основі даних фінансової звітності енергопостачальних компаній за 2010-2016 роки

Як бачимо з рис. 1 , середні структурні фінансові коефіцієнти вхідного грошового потоку енергопостачальних компаній за 2010-2016 роки $є$ різними в розрізі окремих підприємств. У більшості енергопостачальних компаній протягом 2010-2016 років основну питому вагу сукупного вхідного грошового потоку займає вхідний грошовий потік від операційної діяльності.

При цьому у ПАТ «Сумиобленерго» та АК «Харківобленерго» середній коефіцієнт участі вхідного операційного грошового потоку у сукупному грошовому потоці становить 1 . Таке значення даного коефіцієнта є свідченням того, що всі надходження грошових коштів генеруються лише операційною діяльністю зазначених підприємств у 2010-2016 роках. У більшості інших енергопостачальних компаній зазначений коефіцієнт коливається від 0,9 до 1 .

Це $\epsilon$ свідченням того, що операційна діяльність генерує основну частку всіх грошових надходжень даних підприємств протягом досліджуваного періоду. Разом 3 тим $\epsilon$ енергопостачальні компанії, у яких в складі сукупного вхідного грошового потоку значну частку займають надходження від фінансової та інвестиційної діяльності.

До таких підприємств належать: ПрАТ «Рівнеобленерго» (середній коефіцієнт участі 
фінансового та інвестиційного грошового потоку у формуванні сукупного вхідного грошового складає 0,45), ПрАТ «Київобленерго» (середній коефіцієнт участі фінансового та інвестиційного грошового потоку у формуванні сукупного вхідного грошового складає 0,37) та ПАТ «Прикарпаттяобленерго» (середній коефіцієнт участі фінансового та інвестиційного грошового потоку у формуванні сукупного вхідного грошового складає 0,28$)$.

Це зумовлено в першу чергу більшою активністю у фінансово-інвестиційній сфері і як результат - отримання більшого обсягу надходжень грошових коштів від інвестиційної та фінансової діяльностей.

Щодо середніх структурних фінансових коефіцієнтів, які виражають специфіку формування сукупного вихідного грошового потоку енергопостачальних компаній у 20102016 роках (рис. 2), то варто зазначити, що тут також зберігаються структурні пропорції, які притаманні вхідному грошовому потоку. Так, для більшості енергопостачальних компаній протягом 2010-2016 років основу всіх виплат складає вихідний грошовий потік від операційної діяльності.

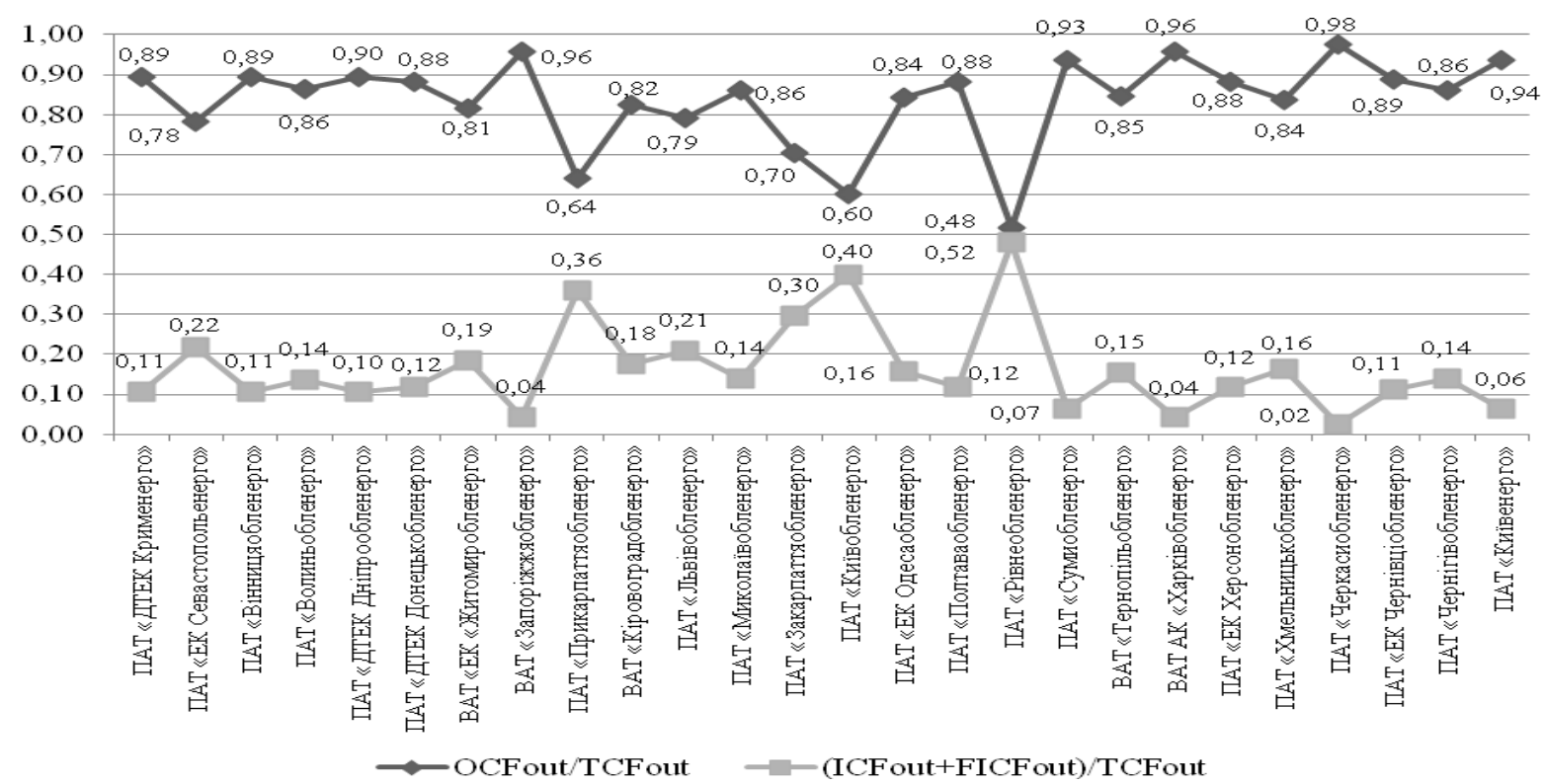

Рис.2 Середні значення коефіціснтів участі OCF енергопостачальних компаній за 2010-2016 роки*

* Побудовано автором на основі даних фінансової звітності енергопостачальних компаній за 2010-2016 роки

Найбільшого значення середній коефіцієнт участі операційного вихідного грошового потоку у сукупному вихідному грошовому потоці набуває у наступних енергопостачальних компаній: ПАТ «Черкасиобленерго» - 0,98, АК «Харківобленерго» - 0,96, ПАТ «Запоріжжяобленерго» - 0,96, ПАТ «Київенерго» - 0,94. При цьому середній коефіцієнт участі інвестиційного та фінансового вихідних грошових потоків у сукупному вихідному грошовому потоці найбільшого значення набуває у ПрАТ «Рівнеобленерго» - 0,48, ПрАТ «Київобленерго» - 0,40, ПАТ «Прикарпаттяобленерго»-0,36. У решти енергопостачальних компаній зазначений показник за 2010-2016 роки коливається від 0,06 до 0,30.

На основі проведеного аналізу коефіцієнтів участі операційного, інвестиційного та фінансового грошових потоків у формуванні сукупного вхідного (вихідного) грошових потоків енергопостачальних компаній можна дійти висновку, що співвідношення між надходженнями (виплатами) від різних видів діяльності суттєво диференціюється в розрізі окремих компаній. Вхідний (вихідний) грошовий потік одних енергопостачальних компаній формується лише за рахунок операційної діяльності, в той час як в інших значну питому вагу займають надходження (виплати) по фінансовій та інвестиційній діяльності. 3 урахуванням зазначеного, для одних енергопостачальних компаній (для тих, в структурі вхідного (вихідного) грошового потоку яких переважають надходження (виплати) по операційній діяльності) в процесі планування вхідного (вихідного) грошового потоку основна увага повинна приділятись надходженням (виплатам) по операційній діяльності. Такі компанії, як 
правило, майже не залучають додатковий капітал на фінансовому ринку та не здійснюють фінансових інвестицій. Фінансування господдарської діяльності відбувається за рахунок внутрішніх фінансових ресурсів, вони проводять пасивну інвестиційну політику та консервативну політику фінансування господарської діяльності.

Коефіцієнти участі операційного, інвестиційного та фінансового грошових потоків у формуванні сукупного вхідного (вихідного) грошового потоку можуть вказувати на цільові планові пропорції, які відображають надходження (виплати) грошових коштів по окремим видам діяльності енергопостачальних компаній. У зв'язку з цим вони з одного боку можуть використовуватись в якості цільових структурних індикаторів формування планового вхідного та вихідного грошових потоків, а 3 іншого - бути ефективними інструментами контролю планових грошових потоків.
На основі проведеного аналізу коефіцієнтів формування вхідного та вихідного грошових потоків енергопостачальних компаній за 20102016 роки можна виділити в якості нормативних коефіцієнтів середньогалузеві їх значення за 2010-2016 роки, які відображені в табл. 1. Дані показники розраховані як середнє арифметичне серед середніх значень коефіцієнтів достатності по кожній з 26 енергопостачальних компаній за період 2010-2016 років. Згідно проведених розрахунків і з урахуванням того, що вибрані в якості об'єкта дослідження енергопостачальні компанії $\epsilon$ основою відповідної галузі (постачання електроенергіi), їх частка в сукупному обсязі становить близько 90\%, то розраховані таким чином фінансові коефіцієнти можуть вважатись середньогалузевими. Розраховані нормативні коефіцієнти участі грошових потоків повністю враховують галузеву специфіку і сферу діяльності енергопостачальних компаній.

Таблиця 1

Нормативні середньогалузеві значення коефіціснтів формування вхідного та вихідного грошових потоків енергопостачальних компаній*

\begin{tabular}{|c|c|c|}
\hline № & Назва коефіцієнта & $\begin{array}{c}\text { Нормативне } \\
\text { середньо-галузеве } \\
\text { значення }\end{array}$ \\
\hline 1 & $\begin{array}{l}\text { Коефіцієнт участі операційного грошового потоку у сукупному вхідному } \\
\text { грошовому потоці }\left(\frac{\left.K_{\text {OCFin }}^{\text {TCFin }}\right)}{}\right. \\
\text { г }\end{array}$ & 0,89 \\
\hline 2 & $\begin{array}{l}\text { Коефіцієнт участі інвестиційного грошового потоку у сукупному вхідному } \\
\text { грошовому потоці }\left(\frac{K_{\text {ICFin }} \text { TCFin }}{)}\right)\end{array}$ & 0,02 \\
\hline 3 & $\begin{array}{l}\text { Коефіцієнт участі фінансового грошового потоку у } \\
\text { грошовому потоці }\left(\frac{\left.K_{\frac{\text { FICFin }}{\text { TCFin }}}\right) .}{}\right.\end{array}$ & 0,09 \\
\hline 4 & $\begin{array}{l}\text { Коефіцієнт участі операційного грошового потоку у сукупному вихідному } \\
\text { грошовому потоці }\left(\frac{K_{\text {OCFout }} \text { TCFout }}{)}\right)\end{array}$ & 0,84 \\
\hline 5 & $\begin{array}{l}\text { Коефіцієнт участі інвестиційного грошового потоку у сукупному вихідному } \\
\text { грошовому потоці }\left(\frac{K_{\text {ICFout }}}{\text { TCFout }}\right),\end{array}$ & 0,06 \\
\hline 6 & $\begin{array}{l}\text { Коефіцієнт участі фінансового грошового потоку у сукупному вихідному } \\
\text { грошовому потоці }\left(\frac{\left.K_{\text {FICFout }}^{\text {TCFout }}\right) .}{}\right.\end{array}$ & 0,10 \\
\hline
\end{tabular}

Щодо можливостей їх практичного застосування в інших галузях і сферах економіки в якості нормативних коефіцієнтів грошових потоків, то на нашу думку, необхідно здійснювати коригування зазначених коефіцієнтів, щоби в повній мірі враховувати специфіку конкретної галузі чи виду діяльності. 3 урахуванням зазначеного вважаємо, що самі по собі коефіцієнти участі грошових потоків $\epsilon$ універсальними інструментами планування та контролю грошових потоків, a їх нормативні значення $\epsilon$ індивідуальними та повинні враховувати специфіку діяльності підприємства.
Зазначені в табл. 1. середньогалузеві нормативні значення можуть використовуватись в якості контрольних індикаторів в процесі планування та контролю грошових потоків. Планові коефіцієнти участі грошового потоку можуть відображати планову (цільову) структуру надходження та вибуття грошових коштів енергопостачальних компаній. Разом 3 тим коефіцієнти участі грошового потоку можуть бути інструментами контролю грошових потоків в процесі порівняння фактичних їх значень 3 плановими та середньогалузевими значеннями. Зазначені властивості фінансових коефіцієнтів 
роблять їх універсальними інструментами планування та контролю грошових потоків підприємств.

Наступною великою групою фінансових коефіцієнтів, які розраховуються на базі грошових потоків, є коефіцієнти достатності грошового потоку. Вони $\epsilon$ співвідношенням вхідного та вихідного грошових потоків та показують чи достатньо надходжень грошових коштів від даного виду діяльності для здійснення виплат по даному виду діяльності або виплат по підприємству в цілому. Можна виділяти коефіцієнти достатності грошового потоку в розрізі видів діяльності: коефіцієнт достатності грошового потоку від операційної діяльності, коефіцієнт достатності грошового потоку від інвестиційної діяльності, коефіцієнт достатності грошового потоку від фінансової діяльності (як варіант при низьких значеннях даних коефіцієнтів застосовувати коефіцієнт достатності грошових коштів від інвестиційної та фінансової діяльності).
Досить важливими коефіцієнтами достатності грошових потоків $є$ коефіцієнти достатності сукупного грошового потоку в розрізі окремих видів діяльності. Зазначені коефіцієнти показують яка частка сукупного вихідного грошового потоку може бути покрита за рахунок вхідного грошового потоку від кожного 3 видів діяльності. Узагальнені характеристики коефіцієнтів достатності операційного, інвестиційного, фінансового та сукупного грошових потоків в розрізі окремих компаній відображені на рис. 3 .

Як бачимо 3 рис. 3 середнє значення коефіцієнта достатності операційного грошового потоку дорівнює одиниці у ПАТ «Сумобленерго» та у ВАТ «ЕК «Харківобленерго». Такі значення даного коефіцієнта відображають ситуацію, коли обсягу генерованого операційною діяльністю вхідного грошового потоку достатньо для здійснення всіх виплат по операційній, інвестиційній та фінансовій діяльностях.

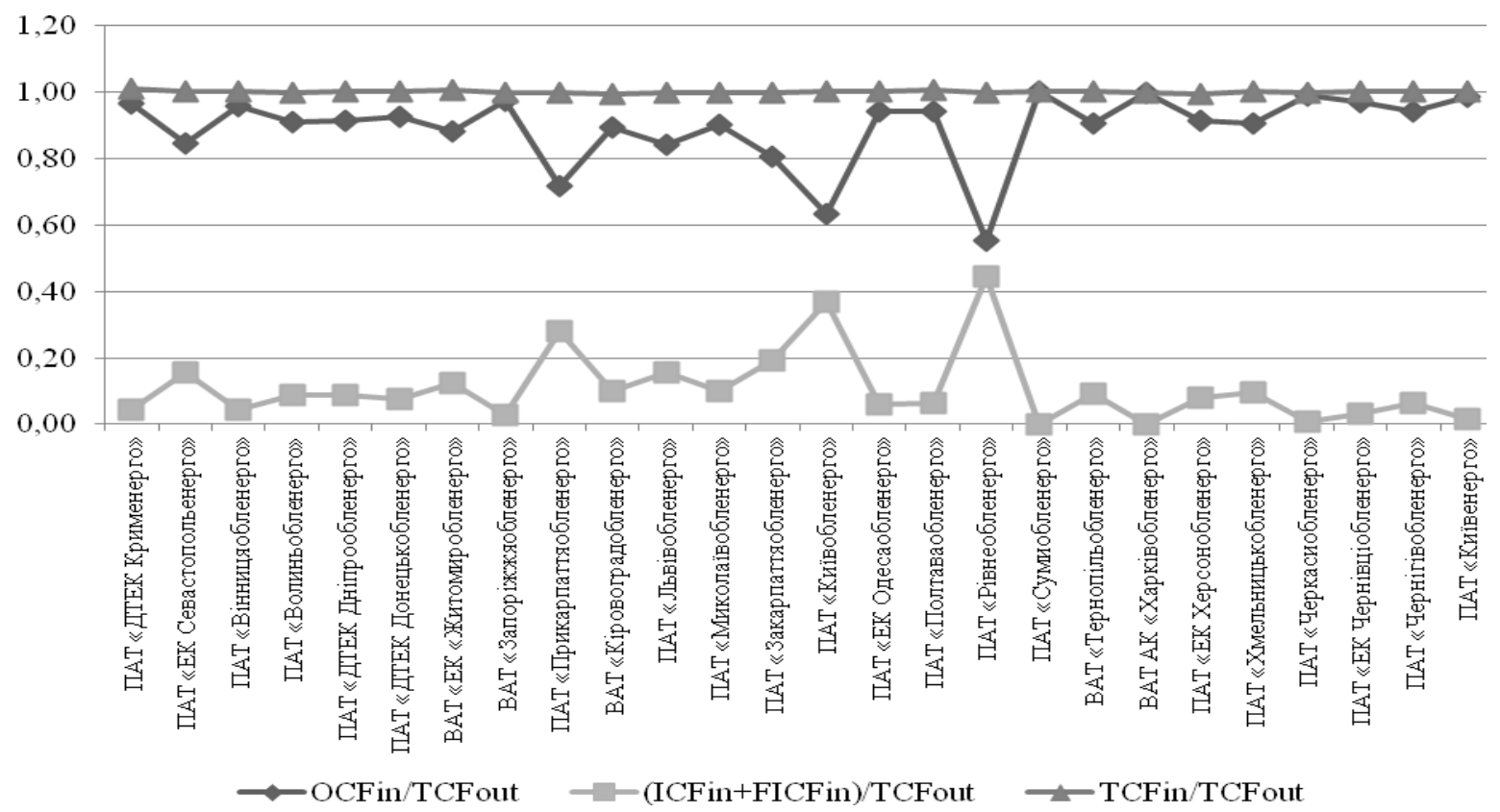

Рис.3 Середні значення коефіціснтів достатності операційного, інвестиційного, фінансового і сукупного грошових потоків енергопостачальних компаній за 2010-2016 рр.*

* Побудовано автором на основі даних фінансової звітності енергопостачальних компаній за 2010-2016 роки

У більшості інших енергопостачальних компаній зазначений показник за 2010-2016 роки коливається від 0,81 до 0,99 , що є свідченням того, що генерований операційною діяльністю вхідний грошовий потік покриває переважну частину всіх виплат підприємства. Разом з тим $\epsilon$ енергопостачальні компанії, у яких є значним значення середнього коефіцієнта достатності грошового потоку від інвестиційної та фінансової діяльностей. До таких енергопостачальних компаній належать: ПАТ «Рівнеобленерго - 0,45, ПАТ Київобленерго»0,37, ПАТ «Прикарпаттяобленерго» - 0,28. Згідно проведеного аналізу за 2010-2016 роки на основі коефіцієнтів достатності грошових потоків енергопостачальних компаній можна дійти висновку, що протягом досліджуваного періоду обсягу генерованих операційною 
діяльністю надходжень грошових коштів достатньо для покриття всіх виплат по операційній діяльності, при цьому у деяких енергопостачальних компаній значна частина сукупного вихідного грошового потоку покривається за рахунок надходжень від фінансової та інвестиційної діяльності. На нашу думку, коефіцієнти достатності грошових потоків можуть бути використані в якості цільових індикаторів в процесі планування та контролю грошових потоків, оскільки виступають агрегованими критеріями, що відображають взаємозв'язок між надходженнями та виплатами грошових коштів. Разом 3 тим проведений аналіз коефіцієнтів достатності грошових потоків енергопостачальних компаній за 2010-2016 роки дозволяє визначити нормативні середньогалузеві значення зазначених коефіцієнтів, які відображені в табл. 2.

Таблиця 2

Нормативні середньогалузеві значення коефіціснтів достатності грошових потоків енергопостачальних компаній*

\begin{tabular}{|c|c|c|}
\hline № & Назва коефіцієнта & Значення \\
\hline 1 & Коефіцієнт достатності сукупного грошового потоку $\left(\frac{K_{\text {TCFin }}}{\text { TCFout }}\right)$ & 1,00 \\
\hline 2 & Коефіцієнт достатності операційного грошового потоку $\left(\frac{K_{\text {oCFin }}}{\text { TCFout }}\right)$ & 0,89 \\
\hline 3 & Коефіцієнт достатності інвестиційного грошового потоку $\left(\frac{K_{\text {ICFin }}}{\text { TCFout }}\right)$ & 0,01 \\
\hline 4 & Коефіцієнт достатності фінансового грошового потоку $\left(\frac{K_{\text {FICFin }}}{\text { TCFout }}\right)$ & 0,10 \\
\hline
\end{tabular}

Зазначені середньогалузеві коефіцієнти достатності грошових потоків енергопостачальних компаній за 2010-2016 роки можуть бути використані в якості нормативних індикаторів в процесі планування та контролю грошових потоків. При цьому сприятливим 3 позиції ефективності управління грошовими потоками буде перевищення фактичних значень коефіцієнтів достатності грошових потоків над їх нормативними значеннями.

Результуючою групою фінансових коефіцієнтів, побудованих на базі грошових потоків, $\epsilon$ коефіціснти ефективності грошових потоків. Зазначені коефіцієнти $\epsilon$ співвідношенням чистого грошового потоку до величини операційного, інвестиційного, фінансового та сукупного грошових потоків. Фактично вони показують яка частка вхідного грошового потоку залишається в розпорядженні підприємства після здійснення всіх виплат. Відповідно чим вищим $\epsilon$ даний коефіцієнт, тим ефективнішим $\epsilon$ підприємство 3 позиції максимізації обсягу грошових коштів, які $\epsilon$ в його розпорядженні.

Базовим коефіцієнтом ефективності грошових потоків $\epsilon$ коефіцієнт ефективності операційного грошового потоку. Фактично він показує співвідношення чистого грошового потоку від операційної діяльності до величини вхідного грошового потоку від цього виду діяльності, відображаючи фактично яка частка вхідного грошового потоку залишається в розпорядженні підприємства після здійснення всіх виплат по операційній діяльності. Загальні тенденції, які виражає середній коефіцієнт ефективності операційного грошового потоку енергопостачальних компаній протягом 20102016 років відобразимо на рис.4.

Як бачимо $з$ рис. 4. протягом досліджуваного періоду середні значення коефіцієнтів ефективності операційного грошового потоку більші нуля, що є позитивною тенденцією. Разом 3 тим варто відмітити, що деякі енергопостачальні компанії є більш ефективними 3 позиції генерування операційною діяльністю грошових потоків, виходячи зі значення середнього коефіцієнту ефективності операційного грошового потоку. До таких енергопостачальних компаній можна віднести: ПрАТ «Закарпаттяобленерго», ПАТ «ЕК «Одесаобленерго», ПАТ «Прикарпаттяобленерго». Разом $з$ тим найменш ефективними згідно даного критерію є: ПАТ «Дніпрообленерго», ПАТ «Черкасиобленерго», ПАТ «Запоріжжяобленерго». 


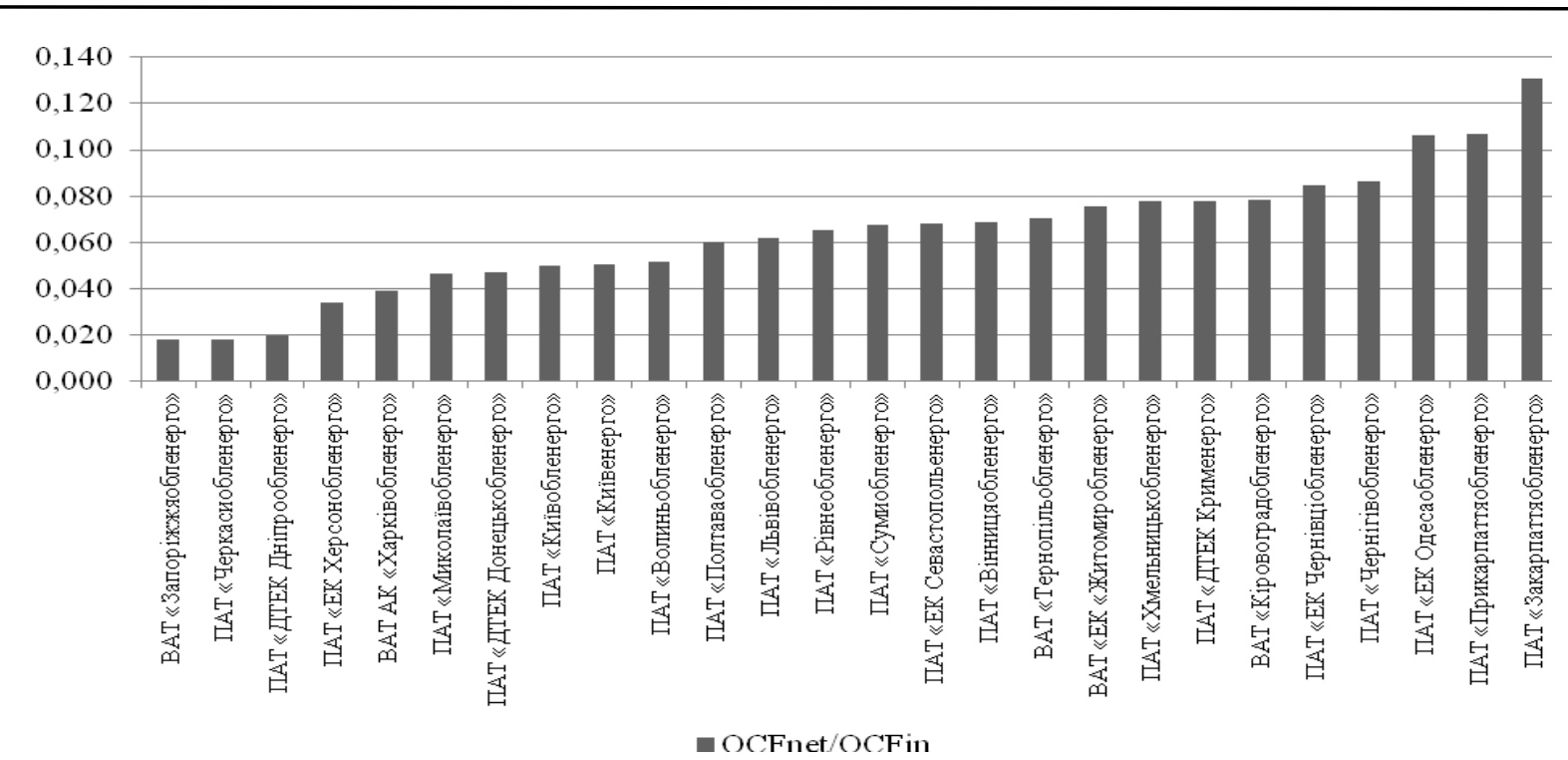

Рис.4 Середнє значення коефіцієнта ефективності операційного грошового потоку енергопостачальних компаній за 2010-2016 рр.*

* Побудовано автором на основі даних фінансової звітності енергопостачальних компаній за 2010-2016 роки

Ключовим узагальнюючим показником, що характеризує ефективність грошових потоків, $\epsilon$ коефіцієнт ефективності сукупного грошового потоку, який показує яка частка сукупного вхідного грошового потоку залишається на підприємстві після здійснення всіх виплат по операційній, інвестиційній і фінансовій діяльності. 3 метою відображення узагальнених тенденцій щодо ефективності сукупного грошового потоку енергопостачальних компаній за 2010-2016 роки побудуємо рис.5, на якому відобразимо середнє значення коефіцієнта ефективності сукупного грошового потоку по кожній із енергопостачальній компаній.

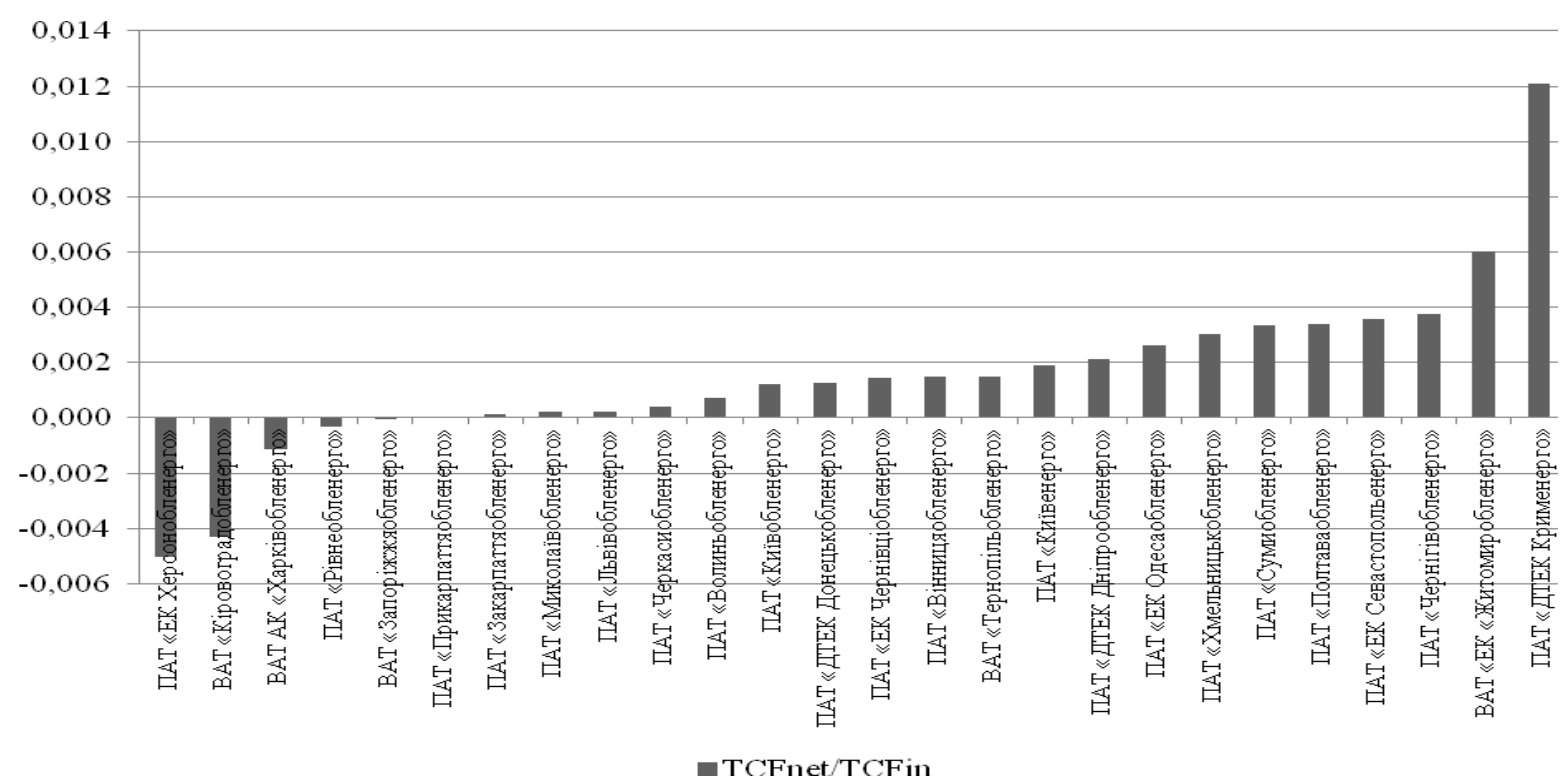

Рис.5. Середнє значення коефіцієнта ефективності сукупного грошового потоку енергопостачальних компаній за 2010-2016 роки*

* Побудовано автором на основі даних фінансової звітності енергопостачальних компаній за 2010-2016 роки

Як бачимо 3 рис. 5. у деяких енергопостачальних компаній спостерігається від'ємне значення коефіцієнта ефективності грошових потоків. До таких енергопостачальних компаній належать: ПрАТ «Кіровоградобленерго», АК «Харківобленерго та ПрАТ «ЕК 
Херсонобленерго». Найвищим середній коефіцієнт ефективності грошових потоків $є$ у: ПАТ «ДТЕК «Крименерго», ВАТ «ЕК Житомиробленерго», ПАТ «Чернігіобленерго». $\mathrm{y}$ решти компаній досліджуваний показник набуває середніх значень.

На основі порівняння коефіцієнтів ефективності операційного та сукупного грошових потоків бачимо, що відмічається ситуація, при якій в одних енергопостачальних корпорацій (наприклад Закарпаттяобленерго) при досить високому середньому значенні коефіцієнта ефективності операційного грошового потоку відмічається низьке середнє значення ефективності сукупного грошового потоку.

В першу чергу це зумовлено від'ємними значеннями чистих грошових потоків від інвестиційної та фінансової діяльності, які суттєво зменшують сукупний чистий грошовий потік енергопостачальних компаній. На основі проведеного аналізу ефективності грошових потоків енергопостачальних компаній за 20102016 роки можна розрахувати середньогалузеві значення коефіцієнтів ефективності грошових потоків, які відобразимо в табл. 3.

Таблиця 3

Нормативні середньогалузеві значення коефіціснтів ефективності грошових потоків енергопостачальних компаній*

\begin{tabular}{|c|c|c|}
\hline № & Назва коефіцієнта & Значення \\
\hline 1 & Коефіцієнт ефективності операційного грошового потоку $\left(\frac{K_{\text {OCFnet }}}{\text { OCFin }}\right)$ & 0,064 \\
\hline 2 & Коефіцієнт ефективності сукупного грошового потоку $\left(\frac{K_{\text {TCFnet }}}{\text { TCFin }}\right)$ & 0,002 \\
\hline
\end{tabular}

Зазначені нормативні значення коефіцієнтів ефективності грошових потоків можуть бути використані в процесі планування та контролю грошових потоків в якості нормативних індикаторів, які відображають ефективність формування грошових потоків енергопостачальних компаній. При цьому сприятливою 3 позиції максимізації обсягу сукупного чистого грошового потоку є ситуація, коли фактичні значення коефіцієнтів ефективності грошових потоків перевищують їх нормативні значення.

Висновки та перспективи подальших досліджень. Отже, в цілому аналіз фінансових коефіцієнтів, побудованих на базі грошових потоків, засвідчує той факт, що у кожної із досліджуваних енергопостачальних компаній протягом 2010-2016 років ситуація в сфері управління грошовими потоками $\epsilon$ неоднозначною. У одних енергопостачальних компаній обсягу генергованого грошового потоку в процесі операційної, інвестиційної діяльності вистачає для фінансування всіх виплат господарської діяльності, в той час як у інших таких надходжень недостатньо для фінансування інвестиційної та здійснення виплат по фінансовій діяльності. 3 метою усунення даних негативних тенденцій енергопостачальним компаніям варто більше уваги приділяти процесам планування та контролю грошових потоків задля виявлення можливостей щодо максимізації обсягу чистого грошового потоку та підвищення ефективності управління грошовими потоками в цілому. В якості планових індикаторів пропонується використовувати цільові значення коефіцієнтів участі, достатності та ефективності грошових потоків, які дозволять 3 одного боку визначити чіткі планові орієнтири для процесу планування грошових потоків, а 3 іншого - виступатимуть інструментами контролю грошових потоків.

Практично-орієнтовані результати аналізу грошових потоків енергопостачальних компаній даного дослідження в подальшому стануть основою розробки методики планування та контролю грошових потоків від операційної, інвестиційної та фінансової діяльностей підприємств в частині використання фінансових коефіцієнтів, побудованих на базі грошових потоків в якості інструментів їх планування та контролю.

\section{ПЕРЕЛІК ВИКОРИСТАНИХ ДЖЕРЕЛ}

1. Брігхем Ю. Эрхардт М. Фінансовий менеджмент - П.:, 2009. - 960 с. - (10-е вид.). - (Академія фінансів), c. $73-74$

2. Теннет Д. Управління грошовими потоками / Джон Теннет; пер с англ. - М.: Альпина Паблишер, 2014. $208 \mathrm{c}$. 
3. Fabozzi F. J. The basics of finance: an introduction to financial markets, business finance and portfolio management / F. J. Fabozzi, - New Jersey, USA: John Wiley \& sons, 2010. - 573 p.

4. Fernandez P. Cash flow is cash and is a fact: net income is just opinion [Електронний pecypc] / Pablo Fernandez // IESE Business school-Universidad de Navarra. - 2006. - Режим доступу до ресурсу: http://www.iese.edu/research/pdfs/DI-0629-E.pdf.

5. Merna T., Al-Thani F. Corporate risk management. - Padstow, Cornwall, UK: John Wiley \& sons, 2008. - 440p.

6. Бланк И. А. Управление денежными потоками / Игорь Александрович Бланк. - Киев: Ника-Центр, 2002. $-736 \mathrm{c}$.

7. Виноградова Е. В. Оптимизация управления денежными потоками предприятия: монография / Е.В. Виноградова, А.В. Ластовенко, Т.В. Белопольская. - Донецк: ДонНУЕТ, 2007. - 194 с.

8. Срешко Ю. О. Управління грошовими потоками підприємства : дис. канд. екон. наук : 08.00 .04 / Ю. О. Срешко; Київський політехнічний інститут. Київ, 2011. - 274 с.

9. Іллічова Н. Ю. Теоретичні аспекти аналізу та управління грошовими потоками на підприємстві./ Н. Ю. Іллічова: зб. наук. пр. Державн. екон.-технол. ун-ту транспорту. Сер. : Економіка і управління . - 2012. Вип. 21-22(2). - С. 190-195.

10. Каламбет С.В. Управління операційними грошовими потоками підприємства : монографія / С. В. Каламбет, А. М. Якимова. - Донецьк : Вид-во Дніпр. нац. університету залізничного транспорту ім. академіка В. Лазаряна, 2009. - 122 с.

11. Кемарська Л. Г. Аналіз і моделювання грошових потоків підприємства / Л. Г. Кемарська // Вісн. Хмельниц. нац. ун-ту. Економічні науки. - 2012. - Т. 2, № 5. - С. 132-138.

12. Лігоненко Л. О. Управління грошовими потоками : навч. посіб. - К.: КНТЕУ, 2012. - 327 с.

\section{REFERENCES}

1. Brihkhem Y., Эrkhardt. M. (2009). Finansovyi menedzhment [Financial management]. - Sankt Peterburh: Akademiia finansiv [in Ukrainian].

2. Tennet D. (2014). Upravlinnya hroshovymy potokamy [Cash Flow Management]. - Moscow: Al'pyna Pablysher [in Ukrainian].

3. Fabozzi F. J. (2010). The basics of finance: an introduction to financial markets, business finance and portfolio management. - New Jersey, USA: John Wiley \& sons.

4. Fernandez P. (2006). Cash flow is cash and is a fact: net income is just opinion. - IESE Business schoolUniversidad de Navarra. Retrieved from: http://www.iese.edu/research/pdfs/DI-0629-E.pdf

5. Merna T., Al-Thani F. (2008). Corporate risk management. - Padstow, Cornwall, UK: John Wiley \& sons.

6. Blank Y. A. (2002). Upravlenye denezhnbimy potokamy [Cash flow management] . - Kyev: Nyka-Tsentr [in Ukrainian].

7. Vynohradova E.V., Lastovenko A.V., Belopolskaia T.V. (2007). Optymyzatsyia upravlenyia denezhnymy potokamy predpryiatyia [Optimization of management of cash flows of the enterprise]. - Donetsk: DonNUET [in Ukrainian].

8. Iereshko Y.O. (2011). Upravlinnia hroshovymy potokamy pidpryiemstva [Management of cash flows of the enterprise]. Candidate's thesis. Kyiv: Kyivskyi politekhnichnyi instytut [in Ukrainian].

9. Illichova N.Y. (2012) Teoretychni aspekty analizu ta upravlinnia hroshovymy potokamy na pidpryiemstvi [Theoretical aspects of the analysis and management of cash flows at the enterprise]. Zbirnyk naukovykh prats Derzhavnoho ekonomiko-tekhnolohichnoho universytetu transportu, seriia: Ekonomika i upravlinnia - Collection of scientific works of the State Economic-Technological University of Transport, ser. Economics and Management, 2122(2), 190-195 [in Ukrainian].

10. Kalambet S.V. Yakymova A. M. (2009). Upravlinnia operatsiinymy hroshovymy potokamy pidpryiemstva [Management of operational cash flows of the enterprise]. - Donetsk: Dnipropetrovskyi natsionalnyi universytetu zaliznychnoho transportu imeni akademika V. Lazariana [in Ukrainian].

11. Kemarska L. H. (2012). Analiz i modeliuvannia hroshovykh potokiv pidpryiemstva [Analysis and modeling of cash flows of the enterprise] Visnyk Khmelnytskoho natsionalnoho universytetu, seriia: Ekonomichni nauky Bulletin of the Khmelnytsky National University, ser. Economics, Vol. 2, n.5, 132-138 [in Ukrainian].

12. Lihonenko L. O. (2012). Upravlinnia hroshovymy potokamy [Cash Flow Management]. - Kiev: KNTEU [in Ukrainian].

Одержано 25.02. 2018 р. 